\title{
Woody community dynamics in two fragments of "cerrado" stricto sensu over a seven-year period (1995-2002), MA, Brazil
}

\author{
FABIANA DE GOIS AQUINO ${ }^{1,3}$, BRUNO MACHADO TELES WALTER ${ }^{2}$ and \\ JOSÉ FELIPE RIBEIRO ${ }^{1}$
}

(received: July 5, 2006; accepted: January 4, 2007)

\begin{abstract}
Woody community dynamics in two fragments of "cerrado" stricto sensu over a seven-year period (1995-2002), MA, Brazil). This study was conducted in two fragments of "cerrado" stricto sensu in the Gerais de Balsas Colonization Project, located in southern Maranhão, Brazil. The objective was to evaluate the dynamics of the woody plant community, over seven years (1995-2002). Four transects of $160 \times 20 \mathrm{~m}$ were monitored. All woody plants with a stem diameter $\geq 3 \mathrm{~cm}$, at $0.30 \mathrm{~m}$ above ground level, were recorded. In 1995, 983 and 1,177 stems were sampled in fragments 1 and 2, respectively; in 2002, 1057 and 1406 stems were sampled in the same fragments. In 1995, the Shannon diversity indices $\left(H^{\prime}\right)$ were 3.07 and 3.33 , in fragments 1 and 2, respectively, reaching their maximum value in 2002 of 3.11 and 3.35. The community of fragment 1 showed an increase of $7.5 \%$ in density and $4.4 \%$ in basal area between 1995 and 2002, while in fragment 2 there was an increment of $19.4 \%$ in density and $23.5 \%$ in basal area, over the same period. The annual increment in diameter was $0.13 \mathrm{~cm}^{2} \mathrm{ear}^{-1}$ and $0.17 \mathrm{~cm}_{\text {year }}{ }^{-1}$ in fragments 1 and 2, respectively. The mortality rate was $2.73 \%$ per year in fragment 1 and $4.88 \%$ per year in fragment 2 , while the recruitment rate was $3.25 \%$ per year and $5.86 \%$ per year, respectively. The community presented high recruitment and mortality rates compared to the studies conducted in other sites, indicating a community that was highly dynamic in the period studied.
\end{abstract}

Key words - fragmentation, permanent plots, plant mortality, recruitment, savanna

RESUMO - (Dinâmica de uma comunidade lenhosa em dois fragmentos de cerrado stricto sensu no período de sete anos (1995-2002), MA, Brasil). O presente estudo foi conduzido em dois fragmentos de cerrado stricto sensu, no Projeto de Colonização Gerais de Balsas, sul do Maranhão, Brasil. O objetivo do estudo foi avaliar a dinâmica da comunidade lenhosa no período de sete anos (1995-2002). Foram estabelecidos quatro transectos de $160 \times 20 \mathrm{~m}$ nos fragmentos, onde foram marcadas todas as plantas lenhosas com diâmetro do caule $\geq 3 \mathrm{~cm}$, medidos a 0,30 m acima do solo. Em 1995, 983 e 1.177 plantas foram registradas nos fragmentos 1 e 2, respectivamente, e em 2002, 1.057 e 1.406 plantas foram amostradas nos mesmos locais. Em 1995, o índice de diversidade de Shannon $\left(H^{\prime}\right)$ foi de 3,07 e 3,33, nos fragmentos 1 e 2, respectivamente, alcançando o valor máximo em 2002 (3,11 e 3,35). A comunidade do fragmento 1 aumentou 7,5\% em densidade e 4,4\% em área basal entre 1995 e 2002, enquanto que o fragmento 2 apresentou aumento de 19,4\% na densidade e 23,5\% em área basal, no mesmo período. O incremento anual em diâmetro foi $0,13 \mathrm{~cm} \mathrm{ano}^{-1}$ e $0,17 \mathrm{~cm}^{2}$ ano $^{-1}$ nos fragmentos $1 \mathrm{e} 2$, respectivamente. A taxa de mortalidade foi $2,73 \%$ ano ${ }^{-1}$ no fragmento 1 e $4,88 \%$ ano $^{-1}$ no fragmento 2 , enquanto a taxa de recrutamento foi $3,25 \%$ ano $^{-1}$ e $5,86 \%$ ano ${ }^{-1}$, respectivamente. A comunidade vegetal estudada apresentou altas taxas de recrutamento e mortalidade comparadas à outros trabalhos conduzidos em diferentes localidades, indicando que se trata de uma comunidade altamente dinâmica no período estudado.

Palavras-chave - cerrado, fragmentação, parcelas permanentes, mortalidade, recrutamento

\section{Introduction}

"Cerrado" stricto sensu is a savanna vegetation that presents a continuous grass layer overlaid by a discontinuous tree and shrub layer. This vegetation is one of the main physiognomies located in the Brazilian "cerrado" biome (Eiten 1972, Ribeiro \& Walter 1998, Oliveira-Filho \& Ratter 2002). Originally, the "cerrado"

\footnotetext{
1. Embrapa Cerrados, BR 020, Km 18, Caixa Postal 08223, 73301-970 Planaltina, DF, Brazil.

2. Embrapa Recursos Genéticos e Biotecnologia, Parque Estação Biológica, 70770-900 Brasília, DF, Brazil.

3. Corresponding author: fabiana@cpac.embrapa.br
}

biome covered about two million sq. kilometers in the Brazilian heartland (figure 1) and it is considered one of the world's 25 hotspots (Mittermeier et al. 1999, Myers et al. 2000) partly because of the number of endemic plants, estimated at about 4400 vascular species, and partly because it is endangered. This region is threatened mainly by the high rate of agricultural expansion throughout native areas, and due to the small percentage of protected areas (2.5\%) (Klink et al. 1993, Ratter et al. 1997).

Many studies have provided important information about the "cerrado" stricto sensu vegetation, detailing phytogeographical, physiognomic, floristic and phytosociological patterns (e.g. Ratter \& Dargie 1992, 
Castro et al. 1999, Felfili et al. 1994, Ratter et al. 1996, Mendonça et al. 2000, Ratter et al. 2003). However, it is also very important to evaluate dynamic changes in natural vegetation over time to understand the processes and mechanisms that maintain the community. Furthermore, this knowledge is important in the support of conservation programs.

Unfortunately, as pointed out by Felfili et al. (2000), there is still little information about structural changes in the "cerrado" stricto sensu vegetation. There is an absence of information concerning the influence of the intense agricultural activities on sites of "cerrado" stricto sensu maintained as natural reserves (fragments of natural vegetation). Studies of community dynamics in "cerrado" stricto sensu are essentially restricted to Silberbauer-Gottsberger \& Eiten (1987) in the state of São Paulo, and Sato \& Miranda (1996), Felfili et al. (2000) and Henriques \& Hay (2002) in Brasília, Federal District, Brazil.

The objective of this study was to evaluate changes in floristic composition, diversity and dynamic processes in the woody communities in two fragments of "cerrado" stricto sensu, in southern Maranhão State, Brazil, over a seven-year period (1995-2002).

\section{Material and methods}

Study area - The study was carried out in two fragments of "cerrado" stricto sensu, located in the Gerais de Balsas Colonization Project (8'29' - $8^{\circ} 41^{\prime}$ S and 46 52' - 46 38' W), southern Maranhão State, Brazil (figure 1). This Project is part of the Nippon-Brazilian Cooperation Program for Development of the "cerrado" (Prodecer).

The climate of this region is Aw by the Köppen classification, with an average annual precipitation of 1049 $\mathrm{mm}$ and average temperature of $26^{\circ} \mathrm{C}$ (from Embrapa "cerrados" dataset). The dry season is from April to October, and the rainy season from November to March.

The Gerais de Balsas Colonization Project was established in 1995, with approximately 35,000 ha. In 1994, before its implementation, $99.7 \%$ of the area was composed of native vegetation and the remaining areas were used for subsistence cultivation. In 1995, with the Project in place, half of the area was deforested and converted for commercial agriculture and the remaining area was designated as private reserves - fragments of natural vegetation. This study was developed in two fragments denominated: fragment $1(3,500$ ha) and fragment 2 (1,500 ha) (figure 2). These fragments were monitored from 1995, when the adjacent areas to the fragments were deforested, until 2002.

Fires were registered in both fragments in 1996, 1998, 2000 and 2002. Fragment 2 was intensively burned in 1998.

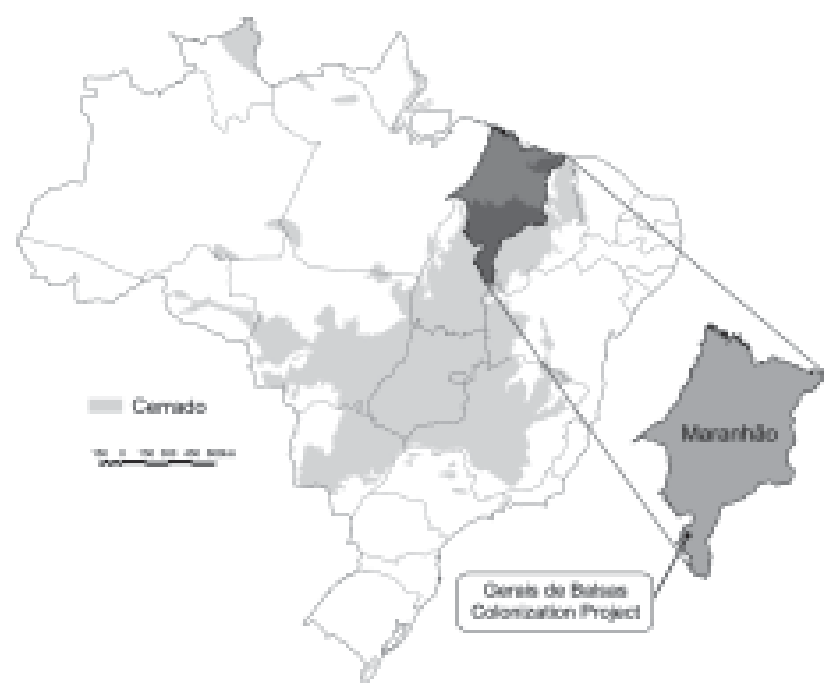

Figure 1. Map of Brazil showing the "cerrado" biome distribution and, in detail, Maranhão State with Gerais de Balsas Colonization Project.

Continuous inventory - Four transects of $160 \mathrm{~m}$, subdivided into 16 contiguous plots of $10 \times 20 \mathrm{~m}$, were established in 1995, with two transects in each fragment. This allowed an area of 1.28 hectares to be monitored. The transects were allocated perpendicular to the edge. They are part of a larger research project that seeks to evaluate the edge effect along 160 meters inside the remaining fragments; for that, contiguous plots that run perpendicular to the edge were used. The first assessment was conducted at the beginning of the wet season of 1995 and the other five inventories occurred in: 1996, 1997, 1998, 2000 and 2002, always in the same season. All woody plants with a stem diameter $\geq 3 \mathrm{~cm}$, at $0.30 \mathrm{~m}$ above ground level, were recorded, tagged and taxonomically identified (sensu APG II 2003). Plants were identified and vouchers were collected and deposited in the

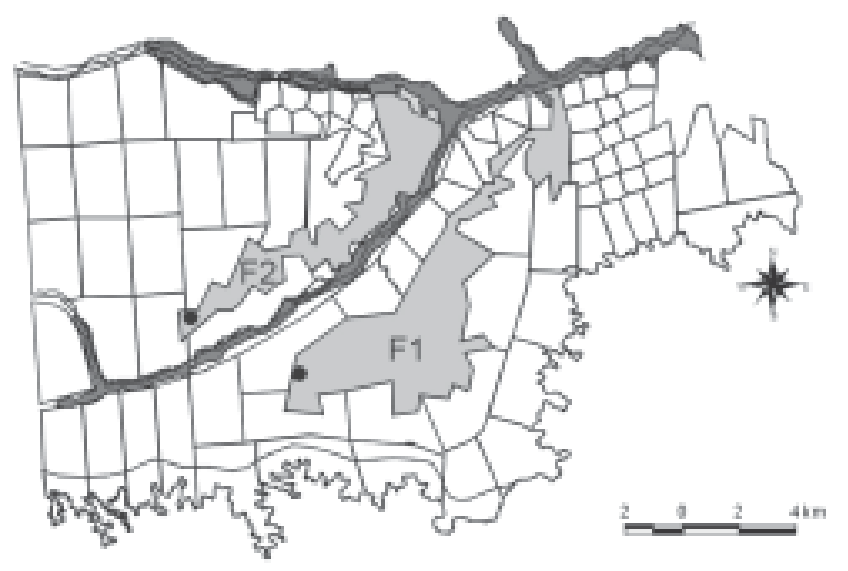

Figure 2. Gerais de Balsas Colonization Project with two areas designated as private reserves - fragment $1(\mathrm{~F} 1)$ and fragment 2 (F2). ( $\quad=$ "Cerrado" stricto sensu; $\square=$ Gallery Forest; $\bullet$ = Study area). 
Embrapa Recursos Genéticos e Biotecnologia herbaria (CEN), in Brasília, Brazil. A nail in the stem allowed the position for diameter measurement to be standardized in successive assessments. Total height and stem diameter were measured during each survey.

A species list was produced for each fragment studied for each survey. Shannon's diversity and Czekanowski's similarity indices were obtained to compare the fragments.

Annual increment in diameter was calculated in each fragment from the average of the differences in increment between the first and last assessments, divided by the study period (seven years).

Mean annual mortality and recruitment rates were calculated using the log-model (Lieberman et al. 1985, Korning \& Balslev 1994, Sheil et al. 1995):

$$
r=\left(C_{\mathrm{t}} / C_{0}\right)^{1 / t}-1
$$

where: $r$ is the mean annual mortality $(r<0)$ or recruitment $(r>0)$ rate, $t$ is the elapse of time in years, and $C_{0}$ and $C_{\mathrm{t}}$ are the stand sizes at time 0 and after $t$ years, respectively.

According to Oliveira Filho et al. (1997) this calculation allows one to evaluate the respective half-lives and doubling times calculated from the above rate. Half-life $\left[t_{1 / 2}=\ln (0,5) / \ln (1+\mathrm{r})\right]$ is the time required by the community to decrease its size to half considering the present mortality rate, while doubling time $\left[t_{2}=\ln (2) / \ln (1+r)\right]$ is the time taken to double its size considering the present recruitment rate. Turnover and stability values were estimated from the average of doubling time and half-life, and the numerical difference between them, respectively (Korning \& Balslev 1994).

\section{Results}

In 1995, 983 and 1177 stems $\geq 3 \mathrm{~cm}$ were sampled in the permanent plots of fragments 1 and 2, respectively, and in the last survey, in 2002, 1,057 and 1,406 stems were sampled in each fragment. In fragment 1, 48 species were recorded in the first two assessments (1995, 1996). In 2000, the single individual representative of Dimorphandra mollis Benth. died. In 2002, six new species were registered, Dimorphandra gardneriana Tul., Emmotum nitens (Benth.) Miers, Machaerium acutifolium Vogel, Miconia albicans (Sw.) Triana, Pterodon emarginatus Vogel and, Salacia elliptica (Mart. ex Schult.) G. Don, resulting in a total of 53 species. In fragment 2, 55 species were registered in the first assessment (1995), and four new species were included in the next two assessments (1996, 1997): Casearia sylvestris Sw., Miconia ferruginata DC., Neea theifera Oerst. and Stryphnodendron adstringens (Mart.) Coville. In the 1998 survey, Casearia sylvestris, Guapira graciliflora (Mart. ex J. A. Schmidt) Lundell, Emmotum nitens and Rourea induta Planch. were not registered in the plots, and in 2000, Neea theifera, Stryphnodendron adstringens and Couepia grandiflora (Mart. \& Zucc.) Benth. ex Hook. f. were not registered. Finally, in 2002, five species (Copaifera langsdorffii Desf., Dimorphandra mollis, Emmotum nitens, Rourea induta and, Stryphnodendron adstringens) were included, resulting in a total of 57 species.

In 1995, the diversity indices were 3.07 and 3.33, in fragments 1 and 2, respectively, reaching a maximum value in 2002 in both sites of 3.11 and 3.35. The Czekanowski index varied from 0.46 to 0.45 , indicating that the sites studied showed qualitative similarity, although quantitative dissimilarity was shown by the varying number of individuals of each species between fragments.

Density and basal area for 19 species with highest number of individuals in 1995 are given in table 1 . In fragment 1, ten species (Hirtella ciliata, Erythroxylum deciduum, Byrsonima coccolobifolia, Sclerolobium paniculatum, Davilla elliptica, Byrsonima crassa, Syagrus comosa, Ouratea hexasperma, Qualea parviflora and Pouteria ramiflora) represented $72 \%$ of the total density and $62 \%$ of total basal area in 1995 . In 2002, the same ten species contained $72 \%$ and $64 \%$ of the total density and basal area, respectively. Although these ten species have mostly shown similar percentages over the seven years in relation to density and basal area, certain species showed considerable changes in these parameters. For instance, Sclerolobium paniculatum more than doubled its density. Connarus suberosus and Platonia insignis halved their densities. Salvertia convallariaeodora increased in density and presented a negative difference in basal area. This was because one individual with an $18 \mathrm{~cm}$ diameter died, while the recruitment included individuals with smaller diameter, close to the lower limit established in the method adopted. Ouratea hexaspema, Mouriri elliptica and Psidium myrsinoides maintained the same densities over the seven years.

In fragment 2, ten species (Ouratea hexasperma, Vochysia rufa, Qualea grandiflora, Salvertia convallariaeodora, Davilla elliptica, Sclerolobium paniculatum, Connarus suberosus, Byrsonima coccolobifolia, Lafoensia vandelliana and Pouteria ramiflora) were responsible for $61 \%$ of the total density and $63 \%$ of the total basal area in 1995 . The same species in 2002 represented $59 \%$ and $60 \%$ of the total density and basal area, respectively. Vochysia rufa, Qualea parviflora and Davilla elliptica increased in 
Table 1. Density (number of stems ha $\mathrm{h}^{-1}$ ) and basal (B.) area $\left(\mathrm{m}^{2} \mathrm{ha}^{-1}\right)$ for 19 species with highest number of individuals in 1995 , in the "cerrado" sensu stricto, Gerais de Balsas Colonization Project, Maranhão, Brazil.

\begin{tabular}{|c|c|c|c|c|c|}
\hline Species in Fragment 1 & Family & $\begin{array}{l}\text { Density } \\
\text { in } 1995\end{array}$ & $\begin{array}{l}\text { Difference } \\
\text { 2002-1995 }\end{array}$ & $\begin{array}{l}\text { B. area } \\
\text { in } 1995\end{array}$ & $\begin{array}{l}\text { Difference } \\
2002-1995\end{array}$ \\
\hline Hirtella ciliata Mart. \& Zucc. & Chrysobalanaceae & 223 & -16 & 1.614 & -0.067 \\
\hline Erythroxylum deciduum A. St.-Hil. & Erythroxylaceae & 203 & -14 & 0.281 & -0.005 \\
\hline Byrsonima coccolobifolia Kunth & Malpighiaceae & 116 & 20 & 0.188 & 0.072 \\
\hline Sclerolobium paniculatum Vogel & Fabaceae Caesalpinioideae & 102 & 103 & 0.385 & 0.135 \\
\hline Davilla elliptica A. St.-Hil. & Dilleniaceae & 94 & -23 & 0.245 & -0.020 \\
\hline Byrsonima crassa Nied. & Malpighiaceae & 88 & 9 & 0.391 & 0.020 \\
\hline Syagrus comosa (Mart.) Mart. & Arecaceae & 84 & -2 & 0.313 & 0.046 \\
\hline Ouratea hexasperma (A. St.-Hil.) Baill. & Ochnaceae & 83 & 0 & 0.229 & 0 \\
\hline Qualea parviflora Mart. & Vochysiaceae & 56 & 3 & 0.567 & 0.120 \\
\hline Pouteria ramiflora (Mart.) Radlk. & Sapotaceae & 53 & 5 & 0.210 & 0.042 \\
\hline Myrcia sellowiana O. Berg & Myrtaceae & 44 & -2 & 0.519 & -0.051 \\
\hline Vatairea macrocarpa (Benth.) Ducke & Fabaceae Faboideae & 34 & -8 & 0.120 & -0.040 \\
\hline Mouriri elliptica Mart. & Melastomataceae & 33 & 0 & 0.113 & 0.018 \\
\hline Psidium myrsinoides O. Berg & Myrtaceae & 31 & 0 & 0.129 & 0.026 \\
\hline Connarus suberosus Planch. & Connaraceae & 31 & -14 & 0.060 & -0.018 \\
\hline Myrcia ochroides O. Berg & Myrtaceae & 28 & -6 & 0.086 & -0.005 \\
\hline Salvertia convallariaeodora A. St.-Hil. & Vochysiaceae & 27 & 3 & 0.878 & -0.121 \\
\hline Platonia insignis Mart. & Clusiaceae & 20 & -9 & 0.072 & -0.046 \\
\hline Rourea induta Planch. & Connaraceae & 17 & -2 & 0.023 & 0.001 \\
\hline Others 29 species in 1995 & - & 169 & 67 & 0.733 & 0.207 \\
\hline Total & & 1536 & & 7.156 & \\
\hline \multicolumn{6}{|l|}{ Species in Fragment 2} \\
\hline Ouratea hexasperma (A. St.-Hil.) Baill. & Ochnaceae & 214 & 53 & 0.428 & 0.073 \\
\hline Vochysia rufa Mart. & Vochysiaceae & 181 & 31 & 0.378 & 0.217 \\
\hline Qualea grandiflora Mart. & Vochysiaceae & 177 & 14 & 0.609 & 0.087 \\
\hline Salvertia convallariaeodora A. St.-Hil. & Vochysiaceae & 101 & 1 & 1.333 & 0.176 \\
\hline Davilla elliptica A. St.-Hil. & Dilleniaceae & 90 & 59 & 0.128 & 0.101 \\
\hline Sclerolobium paniculatum Vogel & Fabaceae Caesalpinioideae & 81 & 8 & 0.228 & 0.071 \\
\hline Connarus suberosus Planch. & Connaraceae & 80 & 11 & 0.177 & -0.026 \\
\hline Byrsonima coccolobifolia Kunth & Malpighiaceae & 69 & 16 & 0.112 & 0.013 \\
\hline Lafoensia vandelliana Cham. \& Schltdl. & Lythraceae & 67 & -12 & 0.210 & -0.029 \\
\hline Pouteria ramiflora (Mart.) Radlk. & Sapotaceae & 64 & 1 & 0.158 & 0.036 \\
\hline Qualea parviflora Mart. & Vochysiaceae & 55 & 45 & 0.420 & 0.177 \\
\hline Syagrus comosa (Mart.) Mart. & Arecaceae & 55 & 5 & 0.168 & 0.008 \\
\hline Eschweilera nana (O. Berg) Miers & Lecythidaceae & 45 & 16 & 0.070 & 0.052 \\
\hline Tabebuia ochracea (Cham.) Standl. & Bignoniaceae & 41 & 6 & 0.108 & 0.021 \\
\hline Psidium laruotteanum Cambess. & Myrtaceae & 39 & 0 & 0.159 & 0.029 \\
\hline $\begin{array}{l}\text { Stryphnodendron rotundifolium } \\
\text { Mart. ex Benth. }\end{array}$ & Fabaceae Mimosoideae & 39 & -11 & 0.042 & -0.010 \\
\hline Erythroxylum suberosum A. St.-Hil. & Erythroxylaceae & 33 & -17 & 0.031 & -0.012 \\
\hline Pouteria torta (Mart.) Radlk. & Sapotaceae & 30 & 17 & 0.049 & 0.026 \\
\hline Hymenaea stigonocarpa Mart. ex Hayne & Fabaceae Caesalpinioideae & 28 & 8 & 0.047 & 0.014 \\
\hline Others 36 species in 1995 & - & 350 & 151 & 1.134 & 0.382 \\
\hline Total & & 1839 & & 5.989 & \\
\hline
\end{tabular}


density and basal area over the seven years. Lafoensia vandelliana decreased in density and basal area, while Psidium laruotteanum Cambess. (=Psidium warmingianum Kiaersk.) maintained the same density over the seven years. Connarus suberosus increased in density and presented negative difference in basal area due to mortality of extremely ramified individuals, with high basal area values, while the recruitment included individuals with smaller diameter, close to the lower limit established in the methods.

In both fragments, the diameter distribution showed a reversed $\mathrm{J}$-shape, as could be expected in a continuously regenerating population (figure 3 ).

Table 2 shows features of vegetation dynamics in both fragments. The community of fragment 1 showed an increase of $7.5 \%$ in density and $4.4 \%$ in basal area between 1995 and 2002, while in fragment 2 there was an increment of $19.4 \%$ in density and $23.5 \%$ in basal area, over the same period. In terms of density, annual recruitment exceeded mortality in both fragments. Consequently, stand half-lives exceeded doubling times. In terms of basal area, the mean annual growth rate exceeded the mean annual mortality rate in fragment 2 and the values of those rates were similar in fragment 1 (table 2). Therefore, stand half-lives exceed doubling times, in fragment 2 . Annual recruitment and mortality
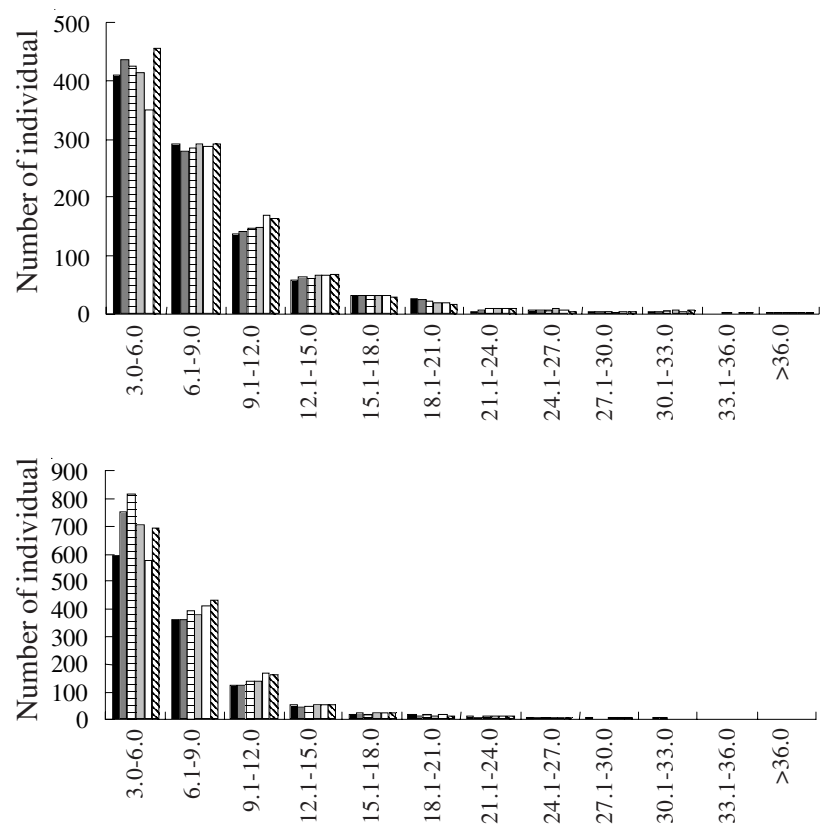

Diameter

Figure 3. Diameter distribution in the "cerrado" sensu stricto of Gerais de Balsas Colonization Project, Maranhão, Brazil. Above: fragment 1; Below: fragment 2. $\square$ 1995; 1996; 亘 1997; $\square$ 1998; $\square 2000$ and $\mathbb{\mathbb { N }} 2002$.
Table 2. Features of dynamics in "cerrado" sensu stricto in Maranhão, Brazil, during the seven-year study period (1995-2002).

Fragment 1 Fragment 2

\begin{tabular}{|c|c|c|}
\hline \multicolumn{3}{|l|}{ Density } \\
\hline Number of plants, 1995 & 983 & 1177 \\
\hline Number of dead plants, $1995-2002$ & 174 & 352 \\
\hline Number of recruits, 1995-2002 & 248 & 581 \\
\hline Number of plants, 2002 & 1057 & 1406 \\
\hline $\begin{array}{l}\text { Mean annual mortality rate } \\
\quad\left(\% \text { year }^{-1}\right)\end{array}$ & 2.73 & 4.88 \\
\hline $\begin{array}{l}\text { Mean annual recruitment rate } \\
\left(\% \text { year }^{-1}\right)\end{array}$ & 3.25 & 5.86 \\
\hline Stand half-life (year) & 25 & 14 \\
\hline Doubling time (year) & 22 & 12 \\
\hline Turnover (year) & 23.5 & 13 \\
\hline Stability (year) & 3 & 2 \\
\hline \multicolumn{3}{|l|}{ Basal area } \\
\hline Total basal area, 1995 & 7.156 & 5.988 \\
\hline Basal area of dead plants, 1995-2002 & 1.566 & 1.030 \\
\hline $\begin{array}{l}\text { Basal area increase of surviving } \\
\text { plants, 1995-2002 }\end{array}$ & 1.704 & 2.162 \\
\hline Basal area of recruits, 1995-2002 & 0.175 & 0.278 \\
\hline Total basal area, 2002 & 7.469 & 7.398 \\
\hline Mean annual mortality rate $\left(\%\right.$ year $\left.{ }^{-1}\right)$ & 3.47 & 2.66 \\
\hline Mean annual growth rate $\left(\%\right.$ year $\left.^{-1}\right)$ & 3.39 & 5.00 \\
\hline Stand half-life (year) & 20 & 26 \\
\hline Doubling time (year) & 21 & 14 \\
\hline Turnover (year) & 20.5 & 20 \\
\hline Stability (year) & 1 & 12 \\
\hline $\begin{array}{l}\text { Annual increment in diameter } \\
\left(\mathrm{cm} \mathrm{year}^{-1}\right)\end{array}$ & 0.13 & 0.17 \\
\hline
\end{tabular}

varied widely depending on the period analyzed, particularly in fragment 2 (table 3 ).

In fragment 1, of the 174 stems that died between 1995 and 2002, 14\% belonged to Sclerolobium paniculatum; $11 \%$ to Erythroxylum deciduum; and $10 \%$ to Davilla elliptica, while, in fragment 2, $10 \%$ of the 352 dead plants in the same period belonged to Ouratea hexasperma; $9 \%$ to Connarus suberosus; and 9\% to Davilla elliptica. In the 1996 and 1997 assessments, more than $70 \%$ of the stems that died measured from 0.5 to 4 meters in height. Of the 248 recruited plants in fragment $1,36 \%$ belonged to Sclerolobium paniculatum; $11 \%$ to Byrsonima coccolobifolia and 5\% to Byrsonima crassa. Of the 581 recruited plants of fragment 2, $12 \%$ belonged to Davilla elliptica; $12 \%$ to Ouratea hexasperma and $7 \%$ to Connarus suberosus. 
Table 3. Mortality and recruitment rates in "cerrado" stricto sensu in Maranhão, Brazil, during the seven-year study period (1995-2002), based on density.

Fragment 1

\begin{tabular}{|c|c|c|c|c|}
\hline Period & Dead & Mortality \% year ${ }^{-1}$ & Recruits & Recruitment $\%$ year ${ }^{-1}$ \\
\hline 1995-1996 & 19 & 1.93 & 39 & 3.97 \\
\hline 1996-1997 & 26 & 2.49 & 24 & 2.29 \\
\hline 1997-1998 & 18 & 1.80 & 22 & 2.20 \\
\hline $1998-2000$ & 81 & 4.17 & 32 & 1.63 \\
\hline \multirow[t]{2}{*}{$2000-2002$} & 30 & 1.53 & 131 & 6.58 \\
\hline & \multicolumn{3}{|c|}{ Fragment 2} & \\
\hline 1995-1996 & 31 & 2.55 & 187 & 15.80 \\
\hline 1996-1997 & 20 & 1.42 & 139 & 10.35 \\
\hline 1997-1998 & 144 & 11.00 & 30 & 0.54 \\
\hline $1998-2000$ & 135 & 5.18 & 69 & 2.55 \\
\hline $2000-2002$ & 22 & 0.87 & 156 & 5.95 \\
\hline
\end{tabular}

\section{Discussion}

Species such as Hirtella ciliata, Dimorphandra gardneriana, Exellodendron cordatum (Hook.f.) Prance, Myrcia ochroides, Platonia insignis and Parkia platycephala Benth. are considered typical of the north-northeast area of "cerrado" distribution (Ratter et al. 1996, 2003), especially in Maranhão State (Eiten 1994), showing the importance of preserving areas chosen as private reserves. Although the number of species has increased in both fragments over seven years, these species have been represented by only one or two young individuals, meaning that they occurred at low density in the plots. Therefore, the increment in the diversity can be considered transitory, because any deaths would eliminate these species from the plots.

The community's annual increment for fragments 1 and 2 , at 0.13 and $0.17 \mathrm{~cm}$ per year, respectively, was similar to that found by Henriques \& Hay (2002) $\left(0.16 \mathrm{~cm}\right.$ year $\left.^{-1}\right)$ in the Federal District, Brazil, and lower than that registered by Silberbauer-Gottsberger \& Eiten (1987) $(0.27 \mathrm{~cm}$ year-1) for "cerrado" stricto sensu in São Paulo, Brazil. Rezende (2002) found a higher increment in diameter, ranging from 0.39 to $0.49 \mathrm{~cm}$ year $^{-1}$, over a period of eleven years in a "cerrado" stricto sensu area in the Federal District, Brazil, as a consequence of slash and burn. These studies indicate a low rate of increment in the aerial parts of plants, which could be associated with poor soils and long droughts (Henriques \& Hay 2002).
Mortality and recruitment rates registered between 1995 and 2002 were high compared to other studies in different sites in Brazil (table 4). These high rates may be associated to human disturbances like fire and fragmentation of native areas, practiced by farmers in these areas.

Mortality registered in this study was higher than the rate obtained by Henriques \& Hay (2002), in the Federal District, Brazil. The high mortality rate recorded may be related to the frequent burning in the study area. Fragment 2 was intensively burned in 1998, which possibly caused the high mortality between 1997 and 1998 (11\% year $\left.{ }^{-1}\right)$ and high instability. The exclusion of four species (Casearia sylvestris, Emmotum nitens, Guapira graciliflora and Rourea induta) was registered in this period. Usually, farmers set fire to private reserves in an attempt to reduce their size and use them as supplementary areas for agriculture in the future; therefore, the natural dynamics of the vegetation is strongly affected.

Some "cerrado" species may present up to $100 \%$ of mortality after burning (Sato \& Miranda 1996, Hoffmann 1998). Miranda et al. (2003) observed that frequent burning can modify "cerrado" lato sensu physiognomies to more open forms, where a larger number of grassy species appear and favor more intense and frequent burning. Fire protection favors firesensitive species and increases the abundance of woody plants in "cerrado" (Moreira 2000).

Additionally, fire may contribute to the high mortality of smaller individuals, mainly young and juvenile 
Table 4. Comparison of the mortality and recruitment rates among some communities of Central Brazil. $(\mathrm{CBH}=\mathrm{Circumference}$ at breast height, $\mathrm{CSL}=$ Circumference at soil level, $\mathrm{DBH}=$ Diameter at breast height, $\mathrm{DBT}=$ Diameter at the base of the trunk and DSL $=$ Diameter at soil level).

\begin{tabular}{llccl}
\hline Vegetation & Inclusion & $\begin{array}{c}\text { Mortality } \\
\left(\% \text { year } \boldsymbol{r}^{-1}\right)\end{array}$ & $\begin{array}{c}\text { Recruitment } \\
\left(\% \text { year }{ }^{-1}\right)\end{array}$ & References \\
\hline Gallery Forest & $\mathrm{CBH} \geq 31 \mathrm{~cm}$ & 3.5 & 2.7 & Felfili(1995) \\
Mesophytic Seasonal Forest & $\mathrm{DBH} \geq 5 \mathrm{~cm}$ & 2.6 & 3.0 & Oliveira Filho et al. $(1997)$ \\
Gallery Forest & $\mathrm{DBT} \geq 5 \mathrm{~cm}$ & 3.7 & 2.03 & Appolinário et al. $(2005)$ \\
Gallery Forest & $\mathrm{DSL} \geq 5 \mathrm{~cm}$ & 2.1 & 2.4 & Van den Berg (2001) \\
"cerrado" stricto sensu & $\mathrm{CSL} \geq 15 \mathrm{~cm}$ & 1.3 & 11.6 & Henriques and Hay (2002) \\
Mesophytic Forest & $\mathrm{CBH} \geq 5 \mathrm{~cm}$ & 2.7 & 3.2 & Pinto (2002) \\
Secondary Forest & $\mathrm{DBH} \geq 8 \mathrm{~cm}$ & 1.7 & 3.5 & Gomes et al. (2003) \\
"cerrado" stricto sensu & Diameter $\geq 3 \mathrm{~cm}$ & $2.7 / 4.9$ & $3.2 / 5.9$ & This study \\
\hline
\end{tabular}

individuals of the woody flora. Sato \& Miranda (1996) also observed that individuals with stem diameter between 5 and $6 \mathrm{~cm}$, measured at $0.30 \mathrm{~m}$ above ground level, and total height under $2 \mathrm{~m}$, presented the highest mortality rates. At the population level, Hoffmann (1998) showed that fire can cause high mortality in seedlings of some woody "cerrado" species, such as Miconia albicans. Therefore, natural mortality on top of fire impact can affect the structure and composition of "cerrado" vegetation.

Recruitment rates obtained here were lower than those registered by Henriques \& Hay (2002) for a "cerrado" stricto sensu in Central Brazil (table 4). However, the recruitment rates found by those authors and in the present study exceed most of those registered for tropical forests (Korning \& Balslev 1994, Phillips \& Gentry 1994) and other "cerrado" studies shown in table 4 , mainly in fragment 2, where there was high recruitment in the 1995-1997 period. One possible explanation for the high recruitment in the "cerrado" stricto sensu compared with other physiognomies may be the high capacity of vegetative reproduction inherent to many species.

The highest recruitment rate in relation to mortality resulted from the increase in density from 1995 to 2002. However, variations were observed in recruitment and mortality rates when the intervals of one or two years were analyzed. In fragment 2 , this is evident, as in the 1995-1997 periods the high recruitment rates were followed by high mortality rates. Some studies suggested that the dynamic equilibrium is characterized by a period of high mortality followed by another with high recruitment and so on, maintaining a constant physiognomy (e.g. Felfili 1995).
Felfili et al. (2000) observed that the changes in density and basal area were larger than those found in several tropical forests, and this was attributed to the frequency of disturbances, such as fire, at intervals from three to five years. However, the maintenance of the species' composition, spatial distribution and community structure in these areas indicated that the studied vegetation is still resilient. The same can also be said for the "cerrado" stricto sensu in the study area, where there were changes in density and basal area, associated with disturbances. The communities studied presented high stability, maintaining the original physiognomy during this period, at least in terms of density and general woody species composition. The maintenance of floristic composition and community structure suggests that the "cerrado" stricto sensu was resilient to the disturbances caused by fire and agriculture at least for the sevenyear period studied.

Acknowledgements - The authors are very grateful to Embrapa Cerrados, Campo (Cia. de Promoção Agrícola), Jica (Japan International Cooperation Agency) and Universidade de Brasília (Pós-graduação em Ecologia). In particular we thank José Roberto Rodrigues Pinto and Ernestino Guarino for valuable comments on the manuscript and Nelson de Oliveira Pais, José Ferreira Paixão, Valdeci de Matos Lima and João Benedito Pereira for assistance in the field. This paper is part of a project funded by DIFD and Embrapa Cerrados.

\section{References}

APG II. 2003. An update of the Angiosperm Phylogeny Group classification for the orders and families of flowering plants: APG II. Botanical Journal of the Linnean Society 141:399-436. 
APPOLINÁRIO, V., OLIVEIRAFILHOA.T. \& GUILHERME, F.A.G. 2005. Tree population and community dynamics in a Brazilian tropical semideciduous forest. Revista Brasileira de Botânica 28:347-360.

CASTRO, A.A.J.F., MARTINS, F.R., TAMASHIRO, J.Y. \& SHEPHERD, G.J. 1999. How rich is the flora of Brazilian Cerrados? Annals of the Missouri Botanical Garden 86:192-224.

EITEN, G. 1972. The cerrado vegetation of Brazil. Botanical Review 38:201-341.

EITEN, G. 1994. Duas travessias na vegetação do Maranhão. Universidade de Brasília. Brasília.

FELFILI, J.M. 1995. Growth, recruitment and mortality in the Gama gallery forest in central Brazil over a six-year period (1985-1991). Journal of Tropical Ecology 11:67-83.

FELFILI, J.M., HARIDASSAN, M., MENDONÇA, R.C., FILGUEIRAS, T.S., SILVA JÚNIOR, M.C. \& REZENDE, A.V. 1994. Projeto biogeografia do bioma cerrado: vegetação e solos. Caderno de Geociências 12:75-166.

FELFILI, J.M., REZENDE,A.V., SILVAJÚNIOR, M.C. \& SILVA, M.A. 2000. Changes in the floristic composition of cerrado sensu stricto in Brazil over a nine-year period. Journal of Tropical Ecology 16:579-590.

GOMES, E.P.C., MANTOVANI, W. \& KAGEYAMA, P.Y. 2003. Mortality and recruitment of trees in a secondary montane rain forest in southeastern Brazil. Brazilian Journal Biology 63:47-60.

HENRIQUES, R.P.B. \& HAY, J.D.V. 2002. Patterns and dynamics of plant populations. In The cerrados of Brazil: ecology and natural history of a neotropical savanna (P.S. Oliveira \& R. J. Marquis, eds.). Columbia University Press. New York, p.140-158.

HOFFMANN, W. 1998. Post-burn reproduction of woody plants in a neotropical savanna: the relative importance of sexual and vegetative reproduction. Journal Applied Ecology 35:422-433.

KLINK, C.A., MOREIRA, A.G. \& SOLBRIG, O.T. 1993. Ecological impact of agricultural development in the cerrados. In The world's savannas: economic driving forces, ecological constraints and policy options for sustainable land use (M.D. Young \& O.T. Solbrig, eds.). Paris and Carnforth: UNESCO \& Parthenon Press. p.259-282.

KORNING, J. \& BALSLEV, H. 1994. Growth and mortality of trees in Amazonian tropical rain forest in Ecuador. Journal of Vegetation Science 4:77-86.

LIEBERMAN, D., LIEBERMAN, M., PERALTA, P. \& HARTSHORN, G.S. 1985. Mortality patterns and stand turnover rates in a wet tropical forest in Costa Rica. Journal of Ecology 73:915-924.

MENDONÇA, R.C., FELFILI, J.M., SILVA JÚNIOR, M.C., FAGG, C.W., SILVA, M.A., FILGUEIRAS, T.S. \& WALTER, B.M.T. 2000. Florística da região do Espigão Mestre do São Francisco, Bahia e Minas Gerais. Boletim do Herbário Ezechias Paulo Heringer 6:38-94.
MIRANDA, H.S., SATO, M.N., ANDRADE, S.M.A., HARIDASAN, M. \& MORAIS, H.C. 2003. Queimadas de cerrado: caracterização e impactos. In Cerrados: ecologia e caracterização (L.M.S. Aguiar \& A.J.A. Camargo, eds.). Embrapa Cerrados. Planaltina, DF. p.69-123.

MITTERMEIER, R.A., MYERS, N., GIL, P.R. \& MITTERMEIER, C.G 1999. Hotspots: Earth's biologically richest and most endangered terrestrial ecoregions. CEMEX, S. A. Agrupación Sierra Madre, S. C. Cidade do México.

MOREIRA, A.G. 2000. Effects of fire protection on savanna structure in Central Brazil. Journal of Biogeography 27:1021-1029.

MYERS, N., MITTERMEIER, R.A., MITTERMEIER, C.G., FONSECA, G.A.B. \& KENT, J. 2000. Biodiversity hotspots for conservation priorities. Nature 403:853-858.

OLIVEIRA FILHO, A.T. \& RATTER, J.A. 2002. Vegetation physiognomies and woody flora of the cerrado biome. In The cerrados of Brazil: ecology and natural history of a neotropical savanna (P.S. Oliveira \& R.J. Marquis, eds.). Columbia University Press. New York. p.91-120.

OLIVEIRAFILHO, A.T., MELLO, J.M. \& SCOLFORO, J.R.S. 1997. Effects of past disturbance and edges on tree community structure and dynamics within a fragment of tropical semideciduous forest in south-eastern Brazil over a five-year period (1987-1992). Plant Ecology 131:45-66.

PHILLIPS, O.L. \& GENTRY, A.H. 1994. Increasing turnover through time in tropical forests. Science 263:954-958.

PINTO, J.R.R. 2002. Dinâmica da comunidade arbóreoarbustiva em uma floresta de vale no Parque Nacional da Chapada dos Guimarães, Mato Grosso. Tese de doutorado, Universidade de Brasília, Distrito Federal.

RATTER, J.A. \& DARGIE, T.C.D. 1992. An analysis of the floristic composition of 26 cerrado areas in Brazil. Edinburgh Journal of Botany 53:153-180.

RATTER, J.A., BRIDGEWATER, S., ATKINSON, R. \& RIBEIRO, J.F. 1996. Analysis of the floristic composition of the Brazilian cerrado vegetation of 98 areas. Edinburgh Journal of Botany 53:153-180.

RATTER, J.A., RIBEIRO, J.F. \& BRIDGEWATER, S. 1997. The Brazilian cerrado vegetation and threats to its biodiversity. Annals of Botany 80:223-230.

RATTER, J.A., BRIDGEWATER, S. \& RIBEIRO, J.F. 2003. Analysis of floristic composition of the Brazilian cerrado vegetation III: comparison of the woody vegetation of 376 areas. Edinburgh Journal of Botany 60:57-109.

REZENDE, A.V. 2002. Diversidade, estrutura, dinâmica e prognose do crescimento de um cerrado sensu stricto submetido a diferentes distúrbios por desmatamentos. Tese de doutorado, Universidade Federal do Paraná, Curitiba. 
RIBEIRO, J.F. \& WALTER, B.M.T. 1998. Fitofisionomias do bioma cerrado. In Cerrado: ambiente e flora (S.M. Sano \& S.P. Almeida, eds.). Embrapa Cerrados, Planaltina, DF. p.89-166.

SATO, M.N. \& MIRANDA, H.S. 1996. Mortalidade de plantas lenhosas do cerrado após duas queimadas prescritas. In Simpósio sobre o cerrado: Biodiversidade e produção sustentável de alimentos e fibras nos cerrados (R.C. Pereira \& L.C.B. Nasser, eds.). Embrapa Cerrados. Planaltina, DF. p.204-207
SHEIL, D., BURSLEM, D.F.R.P. \& ALDER, D. 1995. The interpretation of mortality rates measures. Journal of Ecology 83:331-333.

SILBERBAUER-GOTTSBERGER, I. \& EITEN, G. 1987. A hectare of cerrado: I. General aspects of the trees and thick-stemmed shrubs. Phyton 27:55-91.

VAN DEN BERG, E. 2001. Variáveis ambientais e a dinâmica estrutural e populacional de uma floresta de galeria em Itutinga, MG. Tese de doutorado, Universidade de Campinas, Campinas. 